\title{
Tribute to Mike McDougall
}

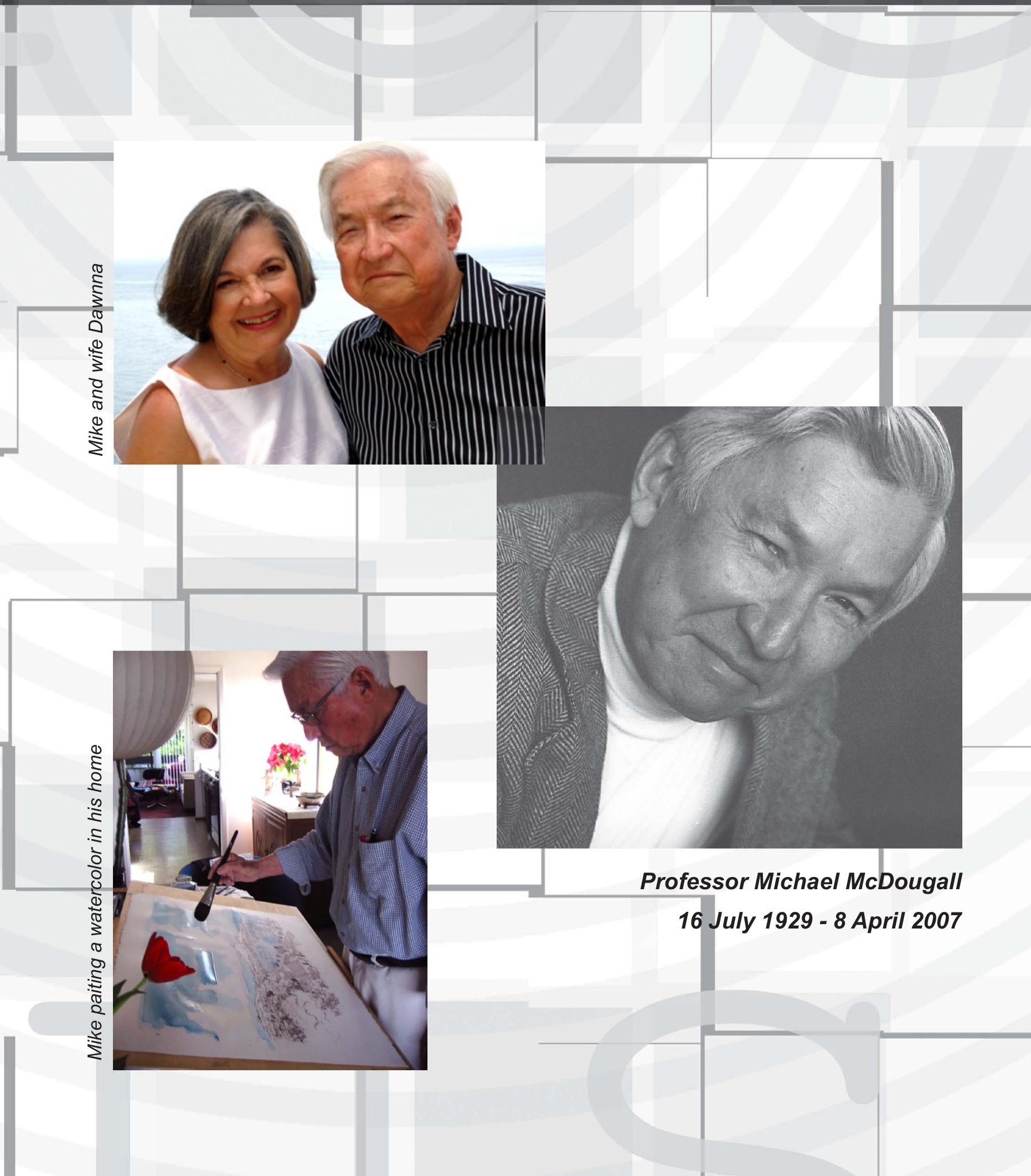

